$\frac{\infty}{\frac{0}{3}}$

DEPARTMENT OF THE INTERIOR

UNITED STATES GEOLOGICAL SURVEY

PALEOVALLEY AND GEOLOGIC MAP OF NORTHEASTERN COLORADO

By Glenn R. Scott 


\section{PALEOVALLEY AND GEOLOGIC MAP OF NORTHEASTERN COLORADO}

$$
\text { By Glenn R. Scott }
$$

\section{INTRODUCTION}

While mapping the geology of the Sterling $1^{\circ} \times 2^{\circ}$ quadrangle, northeastern Colorado (Scott, 1978), I found that the courses of many former streams could be inferred from the preserved remnants of their gravel deposits. After the geologic mapping was completed, the inferred courses of these ancient streams were plotted on a copy of the geologic map of the Sterling quadrangle (Scott, 1978) either directly from stream deposits visible on aerial photographs or by connecting mapped outcrops of gravelly stream deposits. The resulting map shows positions of paleovalleys of seven ages ranging from Oligocene to Quaternary (Illinoian?). In addition, a small scale map (fig. 1) was made that shows postulated ancient stream channels in a larger area of the eastern half of Colorado and adjoining southwestern Nebraska.

The Cenozoic time scale as used here is: The Paleocene Epoch ended 55 (54-56) m.y. ago, the Eocene 38 (34-38) m.y., the Oligocene, 24 (23-26) m.y., the Miocene, 5 (4.9-5.3) m.y., and the Pliocene, $1.8(1.7-2.2)$ m.y. ago.

\section{ACKNOWLEDGMENTS}

I am indebted to G. Edward Lewis of the U.S. Geological Survey for identifying vertebrate fossils I collected in the Sterling area and for supplying much information about the Cenozoic stratigraphy and vertebrate fossils of northeastern Colorado. Robert W. O'Donnell of the U.S. Geological Survey prepared the vertebrate fossils. I also have benefited from discussions and field trips with Glen A. Izett and Norman M. Denson of the U.S. Geological Survey. Cary T. Madden of the University of Colorado Museum and Department of Anthropology provided information about fossil proboscidean teeth found west of Sterling and north of Brush. The trends of paleovalleys in the mountains were derived from work by William A. Braddock of the U.S. Geological Survey and University of Colorado, Charles $\mathrm{E}$. Chapin of the New Mexico Bureau of Mines and Mineral Resources, Rudy C. Epis of the U.S. Geological Survey and Colorado School of Mines, Malcolm E. McCallum of the U.S. Geological Survey and Colorado State University, and Richard B. Taylor of the U.S. Geological Survey.

\section{PREVIOUS WORK ON PALEOVALLEYS AND ORIGIN OF SEDIMENTS}

Many vertebrate paleontologists have collected fossils in northeastern Colorado. Reports on the fossils were written by Matthew (1901), Galbreath (1953), and Wilson (1960). Many reports have been published on the geomorphology of Colorado, Nebraska, Wyoming, and Kansas; however, very little has been written about the paleovalleys or the origin of the paleovalley sediments in the Sterling quadrangle. The following reports are the principal ones on this subject:

In 1951, Schultz and others described the Quaternary deposits of Nebraska and their associated fossils. Along the North Platte River, north of the Sterling quadrangle, the Broadwater Formation of Schultz and Stout (1945), well preserved in the $\mathrm{NE}^{1 / 4}$ sec. 20 , T. 19 N., R. 47 W., Morrill
County, Nebraska, apparently is the earliest post-Ogallala deposit of the Central Great Plains. The formation contains the proboscidean, Stegomastodon, the horse, Dolichohippus, the camel, Gigantocamelus, and other fossils that demonstrate its equivalence with the Blancan (of Pliocene and Pleistocene age) of Texas (Dalquest, 1975). The Broadwater lies almost $490 \mathrm{ft}(150 \mathrm{~m})$ above the North Platte River in Nebraska, nearly the same as the elevation of the Nussbaum Alluvium above the South Platte River in northeast Colorado. Thus, the Broadwater apparently is an age correlative of the Nussbaum Alluvium in the Sterling quadrangle.

In 1964, Smith and others (p. 32-33) discussed a westward shift in the course of the South Platte River from Beebe Draw (fig. 1) to the present valley of the South Platte River. The stream that captured the South Platte was a tributary of the Cache la Poudre River. In addition, they described another capture that involved Box Elder Creek and an ancestral creek in Beebe Draw.

Gardner (1967) mapped the surficial geology of the Orchard, Weldona, and Fort Morgan quadrangles in northeast Colorado, and showed the distribution of Quaternary terrace gravels and a convergence of profiles drawn on the bases of the alluvial deposits as they are traced eastward (Gardner, 1967, fig. 9).

Vondra and others (1969) traced a channel of Gering age (lower part of the Arikaree Formation through the Wildcat Ridge area of western Nebraska. Apparently, the channel was traced by using a characteristic pumice bed in the Gering (Twin Sisters Pumice Conglomerate Bed of Vondra, Schultz, and Thompson, 1969).

Sharps (1969) showed that the Arkansas River migrated across its valley during the Pliocene and Pleistocene in a style very similar to the early migrations of the South Platte River. The migration apparently always was the same direction as the transport direction of the tributaries carrying the greatest quantity of water and sediment. In one reach of the valley, the Arkansas migrated northward; in another reach it migrated southward.

Denson (1969) studied the detrital heavy mineral assemblages in the Miocene and Pliocene (now all included in the Miocene) rocks of central Wyoming and parts of adjacent states. The Arikaree Formation of Oligocene(?) and Miocene age contains a volcanic assemblage characterized by green-brown hornblende and oxyhornblende, augite, hypersthene, and red-brown biotite; the volcanic assemblage, which was largely reworked from ash falls, makes up 70-90 percent of the nonopaque heavy minerals in the formation. According to Denson this suite suggests a time of active volcanism and tectonism far to the west. The Ogallala Formation of Miocene age chiefly contains a metamorphic and plutonic assemblage of nonopaque heavy minerals characterized by blue-green hornblende, garnet, epidote, zircon, tourmaline, actinolite, sphene, and gray-green biotite; the plutonic and metamorphic assemblage makes up more than 46 percent of the nonopaque heavy minerals in the formation and suggests derivation largely from Precambrian 
rocks.

Denson and Chisholm (1971) studied the detrital heavy minerals of the older Tertiary rocks in the middle Rocky Mountains and the northern Great Plains. The Oligocene rocks (White River Group) contain about equal amounts of volcanic and plutonic-metamorphic heavy minerals; the volcanically derived heavy-mineral assemblage generally contains more than 40 percent green-brown hornblende and less than 15 percent augite. More than 30 percent of the heavy minerals is blue-green hornblende, epidote, zircon, garnet, sphene, and green-brown biotite derived from plutonic-metamorphic sources. Thus, the sediments came from distant volcanic sources and from erosion of Precambrian rocks. Most of the Oligocene rocks are very fine grained and contain a low percentage of heavy minerals. The Brule Formation was inferred to be largely of eolian origin whereas the Chadron Formation is almost entirely of fluviatile origin. Denson and Chisholm also believe that the major streams and main drainage framework were in existence at the close of Eocene time and were only slightly modified since then.

Pearl (1971) studied the late Cenozoic erosional history of east central Colorado and northwestern Kansas. He concluded that the Arikaree River was the main river crossing east-central Colorado at the end of Ogallala time; it left the mountains near Pikes Peak, followed the north-eastward trend of modern Big Sandy Creek, then assumed the trend of the present Arikaree River. He inferred that the upper end of the ancestral Arikaree River was captured in Pliocene (p. 1, this report) and Pleistocene time presumably somewhere near Lake George and that afterward the new northeastward course became part of the upper reach of the South Platte River. He also inferred that another capture took place in Pliocene (p. 1, this report) and Pleistocene time when Big Sandy Creek cut headward from the Arkansas River and captured the ancestral Arikaree near present River Bend, Colorado. Presumably Pearl inferred that these two captures so depleted the Arikaree River that it could not cut down through the Ogallala as rapidly as the Arkansas and South Platte Rivers; therefore, its course eastward from River Bend, Colorado, was detached from its headward course. Pearl also stated that removal of the Ogallaia Formation along the east side of the mountains began in late Pliocene (p. 1, this report) time.

Stanley and Wayne (1972) studied the lower Pleistocene fluvial sediments of Nebraska. In particular, they sought information about the provenance of stream gravel and movements of the major early Pleistocene streams through time. Based on the size of clasts in deposits of various ages they determined that the carrying power of early Pleistocene streams was greater than that of either Pliocene (equals(?) Miocene Ogallala) streams or the modern Platte River. They discussed the possible Blancan age of the early post-Ogallala stream deposits in Nebraska. They believed that the granitic gravel in the lower Pleistocene alluvium was derived directly from the Rocky Mountains, not reworked from underlying Tertiary deposits. Shifts in the courses of streams were considered to be the result of spasmodic uplift of folds in the bedrock.

Izett (1975) discussed the late Cenozoic sedimentation and stratigraphy of northeastern Colorado. He equated the Pliocene (5 to 2 m.y. old) approximately with part of the Blancan land mammal age and inferred a period of uplift and erosion prior to the deposition of the Blanco Formation of Texas. He believed that the Arikaree Formation was thinned "by onlap from a northern area along the paleovalley of the North Platte River to a southern area in northeast Colorado." This conclusion was reached because only the upper part (equivalent to Marsland Formation) of the Arikaree crops out in northeastern Colorado. Had the Arikaree been deposited in its entirety and then eroded in pre-Ogallala time only the lower part would have been preserved. From several radiometric ages of volcanic ash beds, he assigned a Miocene age(16-17 m.y. to about 5 m.y.) to the Ogallala Formation. He inferred, from the abrupt increase in grain size in passing from the sandy Arikaree upward into conglomeratic Ogallala, that the Front Range was uplifted several hundred meters at the beginning of Ogallala time. He considered it fairly well established that the South Platte River was in about its present course for the past 10-12 m.y.

Clark (1975) presented evidence for a few stream channels in the White River Group. He described one set of (Chadron) channels trending eastward through the middle of T. 11 N., R. 55 W. Clasts of Proterozoic Sherman Granite characterize this set, but the gravel also contains reddish mudstone and clasts of plutonic rocks of the Front Range from south of the Sherman Granite. A second river (of Chadron age) about $25 \mathrm{mi} \mathrm{(40} \mathrm{km)} \mathrm{south} \mathrm{of} \mathrm{the} \mathrm{first} \mathrm{went} \mathrm{eastward} \mathrm{and}$ turned southeastward north of Sterling. This channel contains neither clasts of Sherman Granite nor red mudstone. He found little volcanic ash in the lower part of the Chadron of northeastern Colorado.

Blackstone (1975, p. 269 and fig. 14) suggested that the 28-27 m.y.-old Specimen Mountain volcanic rocks in Rocky Mountain National Park are a probable source for rhyolitic volcanic clasts found at least $75 \mathrm{mi}(120 \mathrm{~km})$ east of the present mountain front in the upper Tertiary (Ogallala) sedimentary rocks.

Scott (1975) and Epis and others (1976) inferred the routes of streams of Paleocene and later age that flowed out of the mountains and onto the Great Plains. In many of the preserved alluvial deposits, the clasts were traced back to their points of origin; however, because of great later erosion the location of few paleovalleys east of the mountains could be determined with confidence. Paleovalleys of Pliocene and later age in the mountains were easy to locate because of the canyons cut in Pliocene time; contemporaneous paleovalleys along major valleys in the plains were tentatively located from the gravelly valley fills; however, along small valleys with little or no gravel, paleovalleys could not be traced. The above authors mapped an Oligocene stream that crossed the Thirtynine Mile volcanic field, the present site of the Rampart Range, and that deposited the Castle Rock Conglomerate on the plains. Quite likely this stream (the ancestral South Platte River?) also deposited the Chadron Formation in the Fremont Butte area. The same stream later carried Miocene gravel (gravel at Divide, Colo.) eastward, possibly along a trend similar to that of the ancestral Arikaree valley suggested by Pearl (1971). The above authors showed that in Pliocene time this stream was interrupted by several faults and forced into its present course as the South Platte River from Lake George northeastward to Denver. Post-Ogallala cyclic cutting of narrow canyons in the mountains and broader valleys on the plains was described for all large streams; depth of canyons described is as much as $1,640 \mathrm{ft}(500 \mathrm{~m})$.

Stanley (1976) inferred that based on paleocurrents, 
depositional structures, and the geometry of sandstone bodies, the Tertiary streams were similar to modern braided streams on the Great Plains. He concluded that most of the Tertiary fine-grained sandstone originated as alluvial plain deposits and that a smaller part was deposited as eolian sand and loess. Based on the presence of distinctive volcanic clasts in the Arikaree and Ogallala Formations, Stanley (1976, p. $303,304)$ believed that for the first time streams headed in areas west of the Front Range and the Laramie Mountains (in North Park, Colo.). He also reiterated that the Laramie and Medicine Bow Mountains were almost completely buried under Tertiary sediments by Arikaree time, thus helping to explain why the amount of plutonic material in the Arikaree Formation is so small compared to the amount of volcanic material. From his work on petrofacies of the Tertiary rocks he believed that during Oligocene and Miocene time the stream systems shifted progressively southward.

Sharps (1976) and Scott and others (1978) showed that the greater part of the Nussbaum Alluvium north of the Arkansas River is a broad thick alluvial fan deposit, similar to the Ogallala, that grades southeastward into main-stem gravel along the Arkansas River.

\section{PHYSIOGRAPHY}

The two major physiographic features of northeastern Colorado are a high sloping tableland created by the Ogallala Formation (Miocene) and a large and intricately dissected stream-valley system created by the South Platte River and its tributaries. The high tableland is well preserved north and south of the river in virtually its original form. The tableland north of the river can be traced continuously from the Peetz Table westward to the Gangplank where Tertiary clastic rocks overlie Precambrian rocks just west of Cheyenne, Wyo. Well-defined scarps were created where tributaries of the South Platte River cut headward into the tableland. The scarp of the tableland (Chalk Bluffs) north of the river is steeper than the scarp south of the river because the tributaries that have cut headward into the northern bluffs are larger and more active than those south of the river. Excellent exposures of the Ogallala and pre-Ogallala clastic deposits can be seen along the two scarps.

The valley of the south Platte River is broader and deeper (below the tableland formed by the Ogallala Formation) in the west than it is in the east. In the west, from near Pawnee Buttes southeastward to near Akron, the valley is about $70 \mathrm{mi} \mathrm{(112}$ $\mathrm{km})$ wide and about $900 \mathrm{ft}(275 \mathrm{~m})$ deep. In the east near Ovid, the valley is only $5 \mathrm{mi}(8 \mathrm{~km})$ wide and $400 \mathrm{ft}(120 \mathrm{~m})$ deep. Near Fremont Butte, the Ogallala escarpment lies about $18 \mathrm{mi}(29 \mathrm{~km})$ southeast of the river, but near Ovid, it is only 5 miles $(8 \mathrm{~km})$ southeast of the river. From Fremont Butte, the escarpment trends southward out of the quadrangle as far as Lindon, where it turns southwestward to Cedar Point (fig. 1), the highest and westernmost point on the Ogallala Formation, between the South Platte and Arkansas Rivers.

The South Platte River shifted southward through Quaternary time because many streams were bringing water and sediment from the northwest and few from the southeast. The sediment clogged the South Platte River and forced it to move against its southern valley wall. A lack of major tributary streams coming into the South Platte from the south, downstream from Beaver Creek, resulted first from the south Platte River staying close to the scarp and later from eolian sand covering the slope between the scarp and the river.
Except for the trench cut by the South Platte River and its tributaries, the surface on the Ogallala has remained relatively unchanged since its establishment in Miocene time. As the scarp was being cut, all drainage continued to flow eastward on the original surface of the Ogallala.

Many tributaries north and a few south of the river are alined in a northwest direction. The northwest alined tributaries are almost exactly parallel with the direction of the prevailing wind-southeastward at $\mathrm{S} .30^{\circ}-35^{\circ} \mathrm{E}$. I infer that the wind actively assisted in the dissection of the stream channels. Perhaps the streams were further controlled by being forced to stay in channels between long linear dunes. In addition, a case could be made that the stream alinement was in part controlled by the southeast-trending conglomeratic channel deposits of the Chadron Formation (Oligocene); however, this seems unlikely because southeastwardtrending valleys are also fairly abundant south of the river on the Ogallala Formation where the Chadron Formation is not exposed.

A poorly developed tributary stream system along the south side of the river and east of Beaver Creek resulted from deposition of a thick cover of wind-blown sand. The blanket of eolian sand has effectively smothered a northwestward sloping area 3-15 $\mathrm{mi}(5-24 \mathrm{~km})$ wide where rainfall and surface water are quickly absorbed and little or no runoff from the south reaches the river. To the west, Beaver Creek, Badger Creek, Sand Arroyo Creek, Bijou Creek, Kiowa Creek, Lost Creek, and Box Elder Creek have, over the years, developed drainage areas extensive enough to permit them to keep flowing and not be impeded by the eolian sand.

Eolian deposits impose a strong southeastward-trending physiographic pattern on the area. Many of the contacts of the loess and eolian sand parallel the direction of the prevailing wind $\mathrm{S} .30^{\circ}-35^{\circ} \mathrm{E}$. The axes of barchans and linear dunes, some of which are more than $100 \mathrm{ft}(30 \mathrm{~m})$ high, also parallel the wind direction. The large dune field in the southeastern part of the quadrangle is an excellent place to see dune lineation and morphology. The dunes range in age from Pinedale Glaciation to modern; some dunes are still moving. This large dunefield ends at the North Fork of the Republican River; loess lies south of the river. Apparently the sand at the south end of the dune field is carried away by the river as fast as it is deposited on the floodplain.

Several small high landmarks, Pawnee Buttes, Fremont Butte, Twin Buttes, Flattop Butte, and Kirchnavy Butte are erosional remnants of the Tertiary tableland.

An unexplained undrained depression in the southwestern part of T. $5 \mathrm{~N}$., R. $51 \mathrm{~W}$. is thought to be either an unusually large wind blowout or a meteor impact crater. The hollow occupies an area of about $4 \mathrm{mi}^{2}\left(10.4 \mathrm{~km}^{2}\right)$ and has more than 20 smaller hollows downwind (southeast) from it. The meteor origin seems unlikely, but I believe the possibility of finding iron-bearing meteorites should be tested by making a few traverses across the hollow with a hand-held magnetometer. Unfortunately a magnetometer would not detect stony meteorites which apparently are more common.

Remnants of stream terraces and pediments are numerous and well preserved north of the South Platte River, whereas few are preserved on the south side of the river. These surfaces range in age from Pliocene to Holocene, and they lie between $450 \mathrm{ft}(135 \mathrm{~m})$ and less than $10 \mathrm{ft}(3 \mathrm{~m})$ above the present major streams. The terraces are used here to indicate how the position of the ancestral South Platte River 
has changed through time.

\section{PALEOVALLEYS}

The trends of paleovalleys of seven ages have been reconstructed by use of high altitude Army Map Service aerial photographs and the geologic map of the Sterling $1^{\circ} \times 2^{\circ}$ quadrangle (Scott, 1978). A list of the deposits in the paleovalleys and their ages is as follows:

Slocum Alluvium Pleistocene (Sangamon or Illinoian)

Verdos Alluvium Pleistocene (Yarmouth or Kansan)

Rocky Flats Alluvium Pleistocene (Blancan)

Nussbaum Alluvium Pliocene (Blancan)

Ogallala Formation- Miocene-about 18-? m.y. old lower part

Arikaree Formation Miocene-about 20-18 m.y. old (Sterling area only)
White River Group-

Brule and Chadron

Formations

The older three of the above deposits lie one over another with the youngest at the top. The younger four main-stem gravel deposits were laid down on the ancient valley floors of the South Platte River as it continuously cut downward; therefore they are not superposed, and the oldest is topographically the highest. The paleovalleys and their deposits will be discussed from oldest to youngest (table 1).

Brule and Chadron Formations-The Brule and Chadron paleovalleys were recognized by their widespread conglomerate-capped ridges and more local broad sheetlike sandstone and conglomerate deposits, suggesting that there were valleys ranging greatly in width. Indeed, one broad area extending almost unbroken from North Sterling Reservoir to

Table 1.-Stratigraphy of Oligocene and younger deposits in the Sterling $1^{\circ} \times 2^{\circ}$ quadrangle

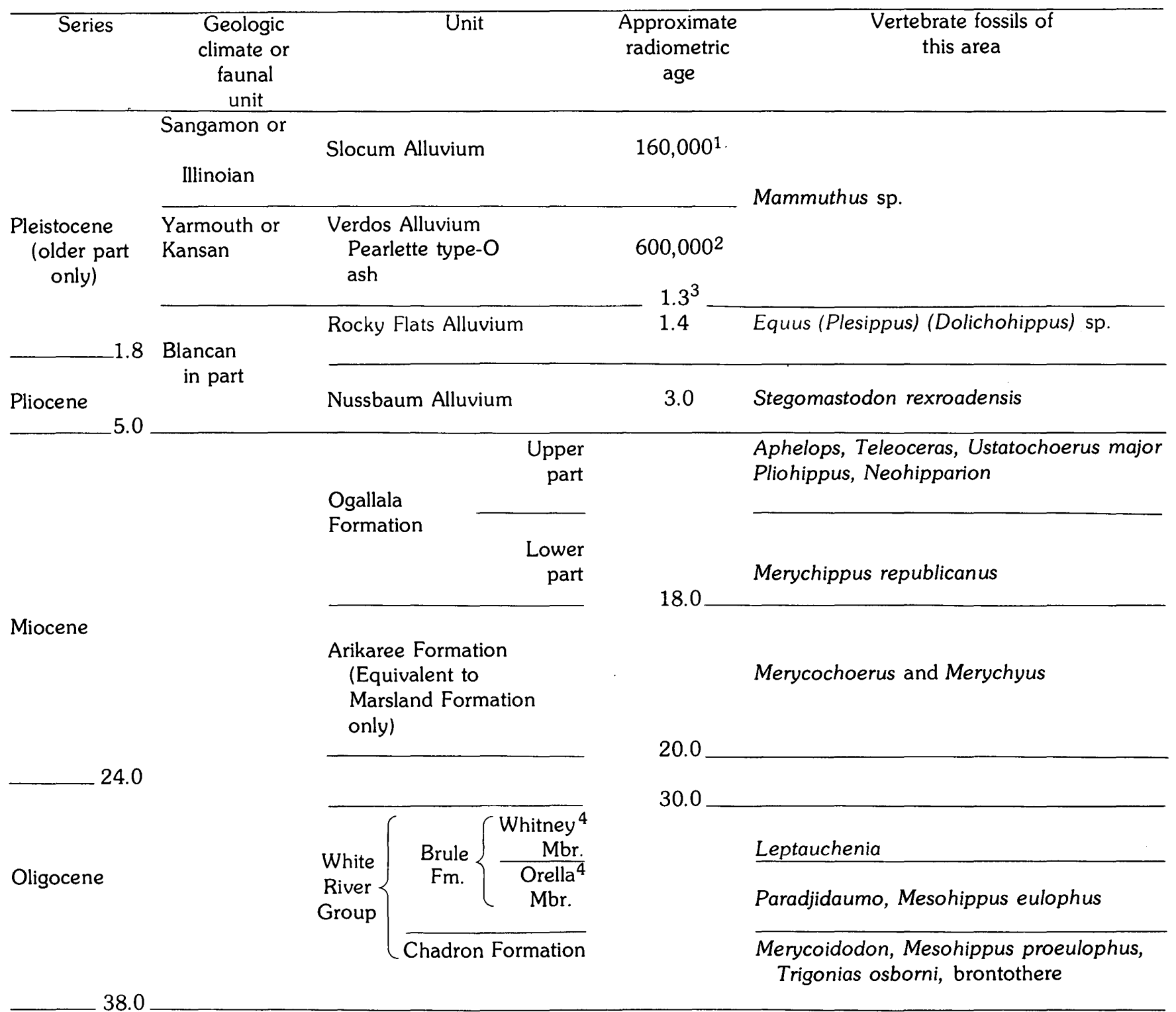

1. Barney J. Szabo, written commun., 1978.

2. Naeser and others, 1973.

3. This and following ages from Glen A. Izett, and John D. Obradovich, oral commun., 1979.

4. Of Schultz and Stout, 1955. 
Willard suggests a probable broad gravel fan rather than the gravel-covered floor of a well-defined stream valley. Conglomerate-filled channels probably are continuous across the quadrangle, but most of the Brule and Chadron are now either buried or removed by erosion. The preserved and exposed channels show two trends; one is a southeastward trend nearly parallel to modern streams, and as stated earlier, might have controlled the locations of the modern streams. The second trend is northeastward from near Pawnee Buttes to Chimney Canyons. Most of these channels are considered to be of Brule age. Channels of both trends contain many topographically high, well-preserved deposits of conglomerate. The deposits are at several different levels, and unless scour took place simultaneously at many depths I suggest that the deposits are of several nearly contemporaneous but slightly different ages. In fact, the material in some of the channels mapped as Brule or Chadron could be as young as the Ogallala Formation. The clasts are chiefly of plutonic and volcanic igneous rocks, but some are of metamorphic and sedimentary rocks. Table 2 shows the composition of the gravel. Fragments of ash-flow tuff similar to ash-flow tuff near Specimen Mountain in Rocky Mountain National Park and fragments of tourmaline-bearing pegmatite suggest a provenance in the Big Thompson River-Rocky Mountain National Park area rather than from the Sherman Granite as suggested by Clark (1975, p. 104). In addition to the sandstone and conglomerate, the Brule and Chadron contain siltstone, limestone, and clay; however, the paleovalleys are recognized by the presence of the sandstone and conglomerate.

\section{Table 2.-Composition of gravel in Chadron Formation} paleovalleys

[Values represent the number of 1- to $2-\mathrm{in} .(2.5-$ to $5-\mathrm{cm})$ pebbles identified by hand lens at three localities: 1) NE $1 / 4$ $\mathrm{NE}^{1 / 4}$ sec. 19, T. 11 N., R. 55 W., Logan Co.; 2) SE 1/4 N1/2 sec. 30, T. 8 N., R. 57 W., Weld Co., and 3) SW1/4 SW1/4 sec. 16, T. 9 N., R. 59 W., Weld Co., Colorado]

\begin{tabular}{|c|c|c|c|}
\hline \multirow[t]{2}{*}{ Rock type } & \multicolumn{3}{|c|}{ Sample localities } \\
\hline & 1 & 2 & 3 \\
\hline Pegmatite & 44 & 61 & 58 \\
\hline Quartz... & 23 & 14 & 19 \\
\hline Feldspar & 5 & 3 & 2 \\
\hline Quartzite . & 10 & 8 & 6 \\
\hline Hornblende gneiss. & 2 & 1 & 1 \\
\hline Hornblende granite & 1 & 0 & 0 \\
\hline Ashflow tuff-reddish-brown ... & 8 & 4 & 6 \\
\hline Porphyry-orange-weathering ......... & 1 & 1 & 2 \\
\hline Porphyry_gray $\ldots \ldots \ldots \ldots \ldots \ldots$ & 3 & 1 & 0 \\
\hline Rhyolite with bipyramidal quartz ..... & 1 & 0 & 0 \\
\hline Felsite-red $\ldots \ldots \ldots \ldots \ldots \ldots \ldots$ & 1 & 0 & 0 \\
\hline Chert $\ldots \ldots \ldots \ldots \ldots \ldots \ldots \ldots \ldots$ & 1 & 0 & 0 \\
\hline Granite . & 0 & 1 & 0 \\
\hline Felsic gneiss .. & 0 & 2 & 3 \\
\hline Quartz diorite & 0 & 1 & 0 \\
\hline Andesite ..... & 0 & 3 & 0 \\
\hline Aplite ............. & 0 & 0 & 1 \\
\hline Ashflow tuff-gray $\ldots \ldots \ldots \ldots \ldots$ & 0 & 0 & 1 \\
\hline Fossiliferous siltstone $\ldots \ldots \ldots \ldots \ldots$ & 0 & 0 & 1 \\
\hline Total & 100 & 100 & 100 \\
\hline
\end{tabular}

The following partial section of the Chadron describes the material in the broad sheetlike deposits near Pawnee Pass in the SE $1 / 4$ sec. 25, T. 8 N., R. 55 W., Logan County, Colorado.

\section{Feet}

Sandstone, coarse- to medium-grained, paleyellowish-brown, olive-gray, or yellowish-gray. Contains granules and clay balls. Highly crossstratified. Contains many fragments of bone and teeth of brontotheres and rhinoceros

Conglomerate composed of granules of quartz and feldspar in a clayey matrix

Claystone, light-olive-gray (damp), yellowishgray (dry), blocky, sandy, silty

Fossil bones of titanotheres and other animals characteristic of the Chadron were found in some of the channel deposits. Fossil bones characteristic of the Brule were found in Brule siltstone topographically below the sandstone and conglomerate in the paleovalleys assigned to the Brule; this evidence supports the assignment to the Brule of these channel deposits.

Arikaree Formation.-Arikaree paleovalleys are characterized by abundant ovoid, biotite-rich, ashy, calcareous siltstone nodules. The trends of three possible paleovalleys were derived from the distribution of Arikaree outcrops on the geologic map. On an early version of the geologic map of Colorado (Burbank and others, 1935), a large area of Arikaree was shown in the area southeast of the South Platte River and east of Sterling. Later, Edward Lewis of the U.S. Geological Survey checked this area and found no Arikaree, but only White River and Ogallala Formations. When I mapped the Sterling quadrangle (Scott, 1978), I found two small areas of rocks I assigned to the Arikaree along the scarp southeast of Sterling. Although diagnostic fossils could not be found, these outcrops were mapped as Arikaree based on lithology similar to that of the Arikaree north of the river. Each of these areas represents a small segment of an inferred paleovalley. Also, a large paleovalley is inferred that trends eastward from Pawnee Buttes to the quadrangle border north of Sedgwick. Fossils diagnostic of Arikaree time were found at several places along this inferred paleovalley. Gravel in the paleovalley is cross-bedded and composed chiefly of gray rounded siltstone nodules, but also of clasts of plutonic and volcanic igneous rocks; clasts are as large as 10 in. $(25 \mathrm{~cm})$. Sand beds are gray, loose to well cemented, cross-stratified, and chiefly composed of quartz and feldspar. According to Denson (1969), the microscopic fraction of fine sand in samples from the Arikaree at Martin Canyon, sec. 27, T. $11 \mathrm{~N}$., R. $53 \mathrm{~W}$., contains 0.8 percent heavy minerals composed of the following percentages of individual minerals: 58 greenish-brown hornblende, 10 augite, 4 oxyhornblende, 1 hypersthene (totaling 73 percent volcanic minerals); 18 bluish-green hornblende, 6 epidote, 1 garnet, 1 sphene, and 1 biotite (totaling 27 percent plutonic and metamorphic minerals.) Apparently most of the volcanic material came from vents west of the high plains.

A section of the Arikaree Formation measured in the SW $1 / 4 \mathrm{SE}^{1 / 4}$ sec. 18 , T. 11 N., R. 50 W., Logan County, Colorado shows the characteristic fluvial lithology and the placement of vertebrate fossils in the formation: 
Gravel, gray, loose to well-cemented, cross-stratified; composed of quartz and feldspar in a sandy to silty matrix. Larger rounded clasts are chiefly siltstone, but include plutonic and volcanic rocks; largest size, 10 in. $(25 \mathrm{~cm})$. Contains fossil bones at USGS locality D920. Merycochoerus cf. M. proprius, 3rd upper molar, fragment of 3rd lower molar. Also fragments of an artiodactyl foot bone

Sand, yellowish-gray, fine, friable, contains orange rusty streaks. Coarse in lower part; contains fossil bones

Conglomerate, gray, clasts to 10 in. $(25 \mathrm{~cm})$, mostly clasts of light-gray siltstone. Cross stratified

Sand, yellowish-gray, loose, cross-stratified in upper half, evenly stratified in lower half

Claystone and siltstone rubble, paleyellowish-brown or yellowish-gray, contains sand in irregular streaks throughout. Contains loose sand and siltstone pebbles in upper part and rarely lower down. Contains fossil bones

Sand, dark-yellowish-gray, loose, contains pebbles of gray siltstone. Composed mostly of quartz and feldspar

\section{Total $\overline{32-33}$}

Ogallala Formation, lower part.-A sinuous paleovalley in the lower part of the Ogallala Formation was extrapolated from contacts on the geologic map. The paleovalley extends from Pawnee Buttes eastward to Martin Canyon where it apparently extends farther eastward under the upper part of the Ogallala Formation. The presence of deep intraformational channels suggests frequent severe erosional activity by the streams. Deposits in the channel (Galbreath, 1953) include cobbly conglomerate lenses cemented by calcium carbonate; brown fine-grained sandstone that locally weathers to a honeycomb appearance; gray or brown soft or slightly indurated silty sand; reddish-brown, light-brown, or grayish-olive calcareous soft or indurated sandy silt that commonly contains layers of gray calcareous siltstone nodules; and several layers of loose to cemented gray volcanic ash as thick as $2 \mathrm{ft}(0.6 \mathrm{~m})$ that contain fossil bones. Some cobbles in the conglomerate apparently came from near Specimen Mountain in Rocky Mountain National Park. Geologic sections 1, $2,3,4,5,8,9$, and 10 of Galbreath (1953) show the characteristics of the above deposits.

The above deposits are equivalent to the upper part of Galbreath's Pawnee Creek Formation (the lower part being nt to my Arikaree). Deposits in the paleovalley contain the jand Canyon local fauna of Wood and others (1941), and the Vim-Peetz, Kennesaw, and Eubanks local faunas of Galbreath (1953). These faunas are characteristic of the Valentine Member of the Ogallala of Condra and Reed (1959) and of the lower Snake Creek Beds of McKenna (1965). The deposits in the paleovalley apparently include two formations as used by vertebrate paleontologists of the American Museum of Natural History (Richard. H. Tedford, written commun., January 9, 1976). The two formations are the Pawnee Creek Formation of "early to late Barstovian age", restricted somewhat from the original definition of Matthew (1901), and an overlying "unnamed formation of the Ogallala Group" of "early Valentinian age."
Ogallala Formation, upper part.-Paleovalleys were not mapped in the upper part of the Ogallala Formation in the Sterling quadrangle. The formation is covered almost everywhere by so thick a Quaternary mantle that channel deposits were not observed. Undoubtedly some channels exist; however, the upper part of the formation probably was deposited as a broad fan and its great thickness, well beyond the possible depth of scour to bedrock, suggests that channeling was not a dominant part of the mode of deposition. The great areal extent of the Ogallala and the way it laps up onto the Laramie Mountains at the Gangplank indicate that it was deposited as a series of broad coalescing fans and that few if any streams were in wellformed discrete channels. Locally, north of Proctor in T. 11 N., R. 49,50 , and $51 \mathrm{~W}$., well-sorted uncemented gravel in the upper part of the Ogallala could possibly be the deposit of a throughflowing braided stream.

Nussbaum Alluvium.-The paleovalley in which the Nussbaum Alluvium was deposited was inferred from outcrops of the alluvium on the geologic map. The belt of outcrops, which lies about $10-12 \mathrm{mi}(16-19 \mathrm{~km})$ north of the river, extends only as far east as Willard. Because the South Platte River valley narrowed to the east, the older stream deposits (Nussbaum and Rocky Flats Alluviums) east of their easternmost outcrops were removed by erosion in post-Nussbaum and in post-Rocky Flats time. In the western part of the valley, there was room for the river to move laterally without destroying all of its earlier deposits, but to the east, the valley was so narrow that all of the Pliocene and lower Quaternary alluviums were eroded from the valley east of Sedgwick.

The Nussbaum paleovalley is preserved as a terrace that was called the Dead Horse terrace by Gardner (1967, p. 141). The Nussbaum paleovalley is about $450 \mathrm{ft}$ ( $137 \mathrm{~m}$ ) above the present floor of the South Platte River northwest of Fort Morgan. This elevation above the river decreases eastward to only $400 \mathrm{ft}(120$ $\mathrm{m})$ northwest of Merino. Thus, the profile of the South Platte River in Nussbaum time converges downstream with the modern profile of the river as also shown by Gardner (1967, fig. 9). This finding, if carried to its obvious conclusion, suggests that the early Quatemary river profiles probably cross the modern river profile and that somewhere in western Nebraska the Pliocene deposits should be overlain by younger deposits in a superposed or layercake sequence. Such a relationship also is implied by Gardner (1967, fig. 9). A sequence like this also is shown by Schultz and others (1951, figs. 1a and 9 and p. 4) along the North Platte River, but poor exposures and lack of detailed mapping of surficial deposits along the South Platte River in southwestern Nebraska has prevented finding such a sequence there.

The Nussbaum paleovalley was wider than $4 \mathrm{mi}(6.4 \mathrm{~km})$ and the alluvium originally was thicker than $70 \mathrm{ft}(21 \mathrm{~m})$. The alluvium is composed of gravel, sand, and silt; clasts in the gravel are chiefly of Precambrian granitic rocks and are larger than the average clast in the Ogallala Formation. The following measured section of the Nussbaum Alluvium shows its typical lithology.

Section near Dead Horse Springs in the SW1/4 sec. 8, T. 5 N., R. 56 W., Morgan County, Colorado.

\footnotetext{
Silt, dark-yellowish-brown, sandy, clayey. The A horizon of a Bull Lake-age soil is developed in the silt. Locally contains a gley (bog) soil as much as 20 in. $(50 \mathrm{~cm})$ thick
} Feet 
Silt, moderate-brown, sandy, clayey, pebbly, has strong medium columnar structure, calcareous in lower part. The $\mathrm{B}$ horizon of a Bull Lake-age soil is developed in the silt

Nussbaum Alluvium:

Silt, grayish-orange-pink, very calcareous, pebbly in the lower part. Contains the $\mathrm{Cca}$ horizon of a pre-Bull Lake-age soil

Gravel, grayish-pink, composed of chert, quartz, pegmatite and granitic clasts

Sand, nearly white, coarse, very calcareous, makes a mortar (calcrete) bed locally

Silt, reddish-brown, clayey, contains light-gray caliche or mortar beds in a reddish-brown clayey silt matrix

Gravel, grayish-pink, contains some clasts 4 in. $(10 \mathrm{~cm})$ in diameter, but average size is about $1 / 4$ in. $(0.6 \mathrm{~cm})$. Elephant bones were found near upper contact

Total Nussbaum Alluvium

69.0

\section{Pierre Shale}

The lower part of the Nussbaum commonly is a resistant conglomerate bed cemented by calcium carbonate from underlying calcareous bedrock. Fossil bones of a camel, horse, and proboscidean have been found in the formation. A large upper tusk, upper last molar, and mandible fragment with partial last molar of a short-jawed proboscidean were found in a gravel pit in the Nussbaum Alluvium in the NE $1 / 4$ SE $1 / 4$ sec. 12 , T. 7 N., R. 55 W., Logan County, Colo. several years ago by Rex Stoltenberg of Sterling. The material was brought to Don Lindsey of the Denver Museum of Natural History and was identified by Cary T. Madden of the University of Colorado Museum and Department of Anthropology. Madden (written commun., 1980) identified the material as Stegomastodon rexroadensis Woodburne, 1961, of early Blancan age (3.0 m.y.?)

Another tooth of a proboscidean was found in 1941 by Victor M. Vondy in a gravel pit in the Nussbaum Alluvium in the NW1/4 NE $1 / 4$ sec. 2, T. 5 N., R. 56 W., Morgan County, Colo. This tooth was identified by Madden in January 1981 as a lower left 3rd molar of Stegomastodon mirificus of middle Blancan age. Based on the above fossils and geomorphic position, the age of the Nussbaum Alluvium is here changed to early and middle Blancan (Pliocene).

Rocky Flats Alluvium.-The Rocky Flats paleovalley was plotted from the distribution of the formation on the geologic map. The paleovalley extends from the west edge of the quadrangle almost as far east as Crook. The northern edge of the paleovalley lies as much as $10 \mathrm{mi}(16 \mathrm{~km})$ north of the river and the valley was more than $4 \mathrm{mi}(6 \mathrm{~km})$ wide. A pediment of this same apparent age was named the Spottlewood pediment by Bryan and Ray (1940, p. 14).

The alluvium consists of reddish-brown fairly well sorted, loose to firmly consolidated, cross-stratified coarse gravel, sand, and silt. Clasts are rounded pegmatite, quartz, granite, quartzite, gneiss, porphyry, chert, and other sedimentary rocks. Some clasts are as large as 12 in. $(30 \mathrm{~cm})$. Thickness of the alluvium probably is more than $30 \mathrm{ft}(9 \mathrm{~m})$. Fossils of the Rocky Flats, including Equus (Dolichohippus) sp. are indicative of a late Blancan age (early Pleistocene). Further support for this age assignment was provided in July 1980, when Cary T. Madden (oral commun.) reported the discovery of a gomphothere tooth by Gordon E. Williams from the Rocky Flats Alluvium at the intersection of Antelope Draw and the Riverside Canal in the NW1/4SW1/4, sec. 7, T. 5 N., R. 55 W., Morgan Co., Colorado. Madden identified the tooth as from the gomphothere Stegomastodon elegans (Hay, 1917). According to Izett (1977) Stegomastodon is not found in beds later than Blancan in age; therefore the Rocky Flats Alluvium is of late Blancan age. Madden (oral commun., 1981) now believes that the Stegomastodon mirificus ( 1.45 m.y.) cited by Izett (1977) from Tule Canyon in the Texas Panhandle is actually Stegomastodon elegans. Based on the above, the age of the Rocky Flats Alluvium is changed from Pleistocene (Aftonian or Nebraskan) to earliest Pleistocene (late Blancan).

The paleovalley lies $200-290 \mathrm{ft}(60-90 \mathrm{~m})$ above the present floor of the South Platte River and slopes downward to the east at an angle steeper than the floor of the South Platte River valley.

Measured section of Rocky Flats Alluvium in a gravel pit in the SW1/4 SE $1 / 4$ sec. 24, T. 6 N., R. 55 W., Morgan County, Colorado.

Loess and wind-blown sand:

Silt. Contains Bull Lake soil. An A horizon in upper 4 in. $(10 \mathrm{~cm}), B$ horizon 16 in. $(40 \mathrm{~cm})$ thick; Cca horizon 20 in. $(50 \mathrm{~cm})$ thick

Sand, eolian

Rocky Flats Alluvium:

Silt and sand, pebbly, contains limestone Feet concretion layers and silt. Impregnated with calcium carbonate of a pre-Bull Lake soil

Gravel, contains typical granitic clasts plus 10-15 sparse amazonstone petrified wood

Verdos Alluvium. - The paleovalley associated with this alluvium was plotted from outcrops shown on the geologic map. In addition to the deposits along the old channel of the South Platte River many deposits were mapped on pediments that slope southward from Chalk Bluffs and the edge of the Peetz Table. The alluvium on the pediments was derived from local sources, partly reworked from older surficial deposits and from bedrock, and contains smaller clasts and less granitic material than the main stem deposits. The pediment-cover material is not mapped as part of the fill in the paleovalley. A pediment apparently of this same age was named the Coalbank pediment by Bryan and Ray (1940, p. 14).

The deposits in the paleovalley are reddish brown, evenly stratified or cross-stratified, loose to firmly consolidated coarse gravel containing sand lenses. Clasts are subangular to rounded and consist of Precambrian pegmatite, quartz, gneiss, quartzite, granite, Tertiary porphyry, Paleozoic chert, and locally other sedimentary rocks. Some boulders are as large as $10 \mathrm{in}$. $(25 \mathrm{~cm})$. Volcanic ash was found in the alluvium at four places: NW1/4SE1/4 sec. 2, T. 8 N., R. $53 \mathrm{~W}$.; NE $1 / 4 \mathrm{SE}^{1 / 1} / 4$ sec. $23, \mathrm{~T} .10$ N., R. 52 W.; Center NE1/4 sec. 23, T. $10 \mathrm{~N}$., R. $52 \mathrm{~W}$. (probably an extension of the previous deposit); and in the NE1/4NW1/4SW1/4 sec. 14, T. 10 N., R. 51 $\mathrm{W}$. All of these deposits probably are Pearlette ash type 0 , or Lava Creek ash bed, a marker volcanic ash bed about 600,000 years old with origin in Yellowstone National Park (Naeser and others, 1973).

The paleovalley lies about $120-160 \mathrm{ft}(36-49 \mathrm{~m})$ above the present channel of the river and the alluvium is about $30 \mathrm{ft}$ $(9 \mathrm{~m})$ thick. The width of the paleovalley probably was more 
than $3 \mathrm{mi}(5 \mathrm{~km})$, however, the deposits are too severely eroded on the south side to permit a good estimate of original width.

Fossils in the Verdos Alluvium include Equus (Equus) caballus; the earlier horse, E. (Dolichohippus) $\mathrm{sp}$. is not characteristic of the Verdos. However, in the Van Gundy gravel pit in the SE $1 / 4 \mathrm{NW}^{1} / 4 \mathrm{sec} .2, \mathrm{~T} .7 \mathrm{~N}$., R. 54 W., M. E. Gardner, then of the U.S. Geological Survey, found teeth of both Equus caballus and E. (Dolichohippus). He believed (Gardner, 1967, p. 61), and I agree, that the teeth of $E$. (Dolichohippus) were reworked from a terrace deposit of Rocky Flats Alluvium, which is immediately upslope from the gravel pit in the Verdos.

Slocum Alluvium.-The paleovalley of the Slocum Alluvium as plotted from the geologic map, lies only 2-3 mi (3-5 km) northwest of the present South Platte River. Pediment remnants lie north of and slope southward into the paleovalley just as they do in the Verdos Alluvium. On the $7 \frac{1}{2}$-minute quadrangle maps, breaks in the slopes of the pediments can be observed where the pediments meet the northern edges of the paleovalleys. Both the pediment cover and the paleovalley fill are mapped as Slocum Alluvium, and the breaks in slope are thought to be the result of later cutting by the South Platte after alluvium stopped accumulating on the pediments. The alluvium on the pediments was eroded from local bedrock and from reworked surficial deposits and was not mapped as part of the paleovalley. The pediment apparently is the same age as the Timnath pediment of Bryan and Ray (1940, p. 23).

The alluvium in the paleovalley is yellowishreddish-brown cross-stratified, loose to slightly consolidated coarse gravel. Alluvium in the paleovalley is coarser than on the pediments; clasts in the paleovalley are as large as 8 in. $(20 \mathrm{~cm})$. The clasts are rounded to subangular and consist of quartz, pegmatite, quartzite, granite, gneiss, porphyry, chert, and other sedimentary rocks. Thickness is as much as $45 \mathrm{ft}(14 \mathrm{~m})$.

The Slocum paleochannel probably was more than 1.5 $\mathrm{mi}(2.4 \mathrm{~km})$ wide; however, that is the width of gravel that now is preserved, the south edge of the paleovalley obviously was removed by erosion. The paleovalley lies about $60 \mathrm{ft}(18 \mathrm{~m})$ above the present channel of the South Platte River.

Post-Slocum time.-Apparently, since Slocum time the South Platte River moved southward a couple of miles, probably during cutting and deposition related to the Louviers Alluvium. Since then, it has moved only slightly to the position it now occupies. The only large terrace along the south side of the river is of the Broadway Alluvium. This alluvium, called "upper member" on the geologic map, was a late phase of Broadway Alluvium that was deposited by tremendous flash floods along Bijou Creek and possibly other tributaries from the south. So much sediment issued from the mouth of Bijou Creek during floods that the South Platte River was temporarily dammed, the alluvium at the mouth of Bijou Creek accumulated to an elevation of $90 \mathrm{ft}(27 \mathrm{~m})$ above the river (at Atwood the top of the terrace is only $15 \mathrm{ft}(4.6 \mathrm{~m})$ above the river), and a broad terrace was created that has prevented the South Platte from being forced against its south valley wall as it was elsewhere. I infer that along most of the reach of the South Platte River in the Sterling quadrangle, the Louviers and Broadway Alluviums are buried beneath alluvium of Holocene age. Several small outcrops of Louviers Alluvium lie along the north side of the river between Sedgwick and Ovid, suggesting that the river course was still moving southward, even after Louviers time.

\section{GEOMORPHIC HISTORY CRETACEOUS TO EOCENE}

Events affecting the history of the paleovalleys began in Late Cretaceous time when the Rocky Mountains started to rise. Some major drainages were established that still are near their original positions (Scott, 1975), and mountains rose that then became continuous sources of clastic sediments. After completion of Laramide uplift of the mountains, most of the southern Rocky Mountain area became tectonically stable for about 10 million years during parts of the Paleocene and Eocene (Epis and others, 1976). A widespread late Eocene surface of low relief was cut on Precambrian rocks. Where developed on the Proterozoic Pikes Peak Granite south of the South Platte River only a few knobs such as Long Scraggy Peak, Devils Head, and Pikes Peak stood above the surface. To the north, in erosion-resistant metamorphic rocks, the surface was cut as more restricted broad valley floors; these valleys from then on controlled rather closely the positions of all streams leaving the mountains. Most of the alluvium produced by cutting of the Eocene surface was carried out of the Denver basin, but a small fraction is preserved in the upper part (nearly $1,000 \mathrm{ft}-300 \mathrm{~m}$ thick) of the Dawson Arkose (Soister and Tschudy, 1978). Large paleovalleys are not obvious in the Eocene part of the Dawson, which apparently originated as coalescing alluvial fans filling a basin.

\section{OLIGOCENE}

In Oligocene time, apparently there was minor uplift in the mountains that triggered erosion by the streams about 35 to $33 \mathrm{~m} . \mathrm{y}$. ago. This activity is documented by conglomerate in the mountains that contains clasts as large as $8 \mathrm{ft}(2.4 \mathrm{~m})$, conglomerate in the Chadron Formation $60 \mathrm{mi}(96.5 \mathrm{~km})$ east of the mountains that contains clasts $1 \mathrm{ft}(0.3 \mathrm{~m})$ in diameter, and bouldery Castle Rock Conglomerate $12 \mathrm{mi}(19 \mathrm{~km})$ east of the mountains that contains clasts $2 \mathrm{ft}(0.6 \mathrm{~m})$ in diameter. Although the streams were carrying coarse alluvium, apparently little more than $100 \mathrm{ft}(30 \mathrm{~m})$ of erosion of Precambrian rock below the late Eocene surface took place. On the plains, meandering streams scoured channels at least $100 \mathrm{ft}(30 \mathrm{~m})$ into underlying sedimentary rocks. Clasts of volcanic rocks in the gravel show that volcanic rocks were being eroded in the mountains. Because some clasts resemble ash-flow tuff near Specimen Mountain with an age of 27-28 m.y. (Corbett, 1968), some of the paleovalleys apparently were filled late in Oligocene time.

From the distribution and character of the Oligocene deposits in the Sterling quadrangle I conclude that they were emplaced by eastward- or southeastward-trending braided streams having some channels filled by coarse sediments. The streams were flowing across unconsolidated basin-fill sediments and moved freely back and forth across the area, inferred from the fact that no well-defined major valley walls or interfluves are apparent. According to Galbreath (1953), fresh-water limestone and massive beds of silt and clay suggest that at least locally vigorous stream activity changed to sluggish streams and possibly marshes, ponds, and lakes.

In later Oligocene time, the fineness of the sandstone and siltstone in the Orella Member of the Brule Formation suggests that the vigorous stream activity that had 
characterized the earlier paleovalleys was decreasing. Nevertheless, the sandstone apparently was deposited in discrete mappable channels. (Unfortunately, time was not available during this study to map these deposits.) The upper part (Whitney Member) of the Brule, is composed of massive tan to gray silt, which, according to Harksen (1969) is a combination of fluviatile and eolian deposits.

\section{MIOCENE}

In early Miocene time, the volcanism that started about 36 million years ago in the mountains to the west continued to produce volcanic flows and crystal-rich ash that were incorporated as clasts in the Arikaree Formation (The Arikaree is Miocene and locally Oligocene(?) in age, but only the early Miocene upper part equivalent to the Marsland Formation has been recognized in northeastern Colorado.) Block faulting began in the mountains about 28 m.y. ago in the Oligocene and channels in the mountains were disrupted. Channel deposits of the Arikaree on the plains apparently were unaffected by the faulting and are spread rather evenly across the Oligocene rocks and are not channeled deeply into them. Deposits of early Miocene age correlative to the Marsland Formation of Nebraska have not been documented in the Front Range, but are known from the lower parts of basin fills in Middle Park (Troublesome Formation) and near Howard, Colo. (Dry Union Formation). The fineness and good sorting of much of the Arikaree on the plains suggest a gentle braided stream, and yet part of the formation is coarse conglomerate and rubble beds that indicate periods of strong currents and great carrying power. The scarcity of channels suggests that the Arikaree was either confined to a few small channels or a great part of it was later removed by streams that deposited the Ogallala Formation.

In late Miocene (Ogallala) time, erosion and channeling into the late Eocene surface on the Precambrian rocks of the mountains ranged from $100-800 \mathrm{ft}(30-240 \mathrm{~m})$ on various streams leaving the Front Range. Some erosion of older units also took place on the plains by the streams that deposited the Ogallala. Generally, however, the Ogallala was laid down by broad shallow aggrading streams that did not cut the earlier sedimentary rocks.

The possibility that these streams had well developed valleys at the end of Ogallala time seems slight, and I do not believe that the present valleys of Frenchman Creek, Republican River, Arikaree River, the Smoky Hill River, or their tributaries existed as well-developed valleys in their present positions at the close of Ogallala deposition.

Both the approximate sources and courses of streams that deposited the Ogallala can be inferred from trends of preserved gravel channels in the mountains (Scott, 1975; and Epis and others, 1976) and from the lithology of clasts in the Ogallala. For instance, one of the channels providing sediments to the Ogallala came from the mountains north of Pikes Peak (Scott, 1975; Epis and others, 1976). I have seen many fragments of amazonstone and smoky quartz from the Pikes Peak Granite in the Ogallala of east central Colorado; in addition, fragments of volcanic rocks similar to those in the Thirtynine Mile volcanic field were found in the Ogallala at Cedar Point. Other streams coming out of the mountains also carried unique rocks and minerals that can be recognized in the Ogallala Formation.

\section{PLIOCENE}

At the beginning of Pliocene time, about 5 m.y. ago, a major change in stream activity took place when alluviation, characteristic of Ogallala time, ceased and downcutting began, with occasional times of stability of base level, when alluvium was deposited. The change probably resulted from uplift of the mountains and increased runoff. Gradients of streams were steepened and deep canyons were cut in the flanks of the mountains. The dissection apparently either caused stoppage of deposition of the Ogallala or started soon after the latest sediments of the Miocene Ogallala Formation were deposited.

The present pattern of streams just east of the mountains suggests that dissection started with streams flowing semi-parallel to the mountain front and emptying into two master streams, the South Platte and Arkansas Rivers. The sudden change from eastward drainage that deposited fan alluvium in the Ogallala Formation to stream dissection semi-parallel to the mountain front apparently came about because the two greatest systems of drainage from the mountains at the end of Miocene time were in the areas west of Canon City and west of Greeley. When dissection began, the headward-cutting tributaries of these two drainage systems cut northward and southward near the mountain front and because they apparently had steeper profiles than the slope on the Ogallala they were able to capture all of the smaller streams coming out of the mountains. Very soon after downcutting started all streams flowing across the Ogallala Formation would have been beheaded except the South Platte and Arkansas Rivers which would have become entrenched into the Ogallala. On the plains, erosion would have been as fast as changing base level would have permitted as the master streams and their new tributaries cut down through nonresistant Tertiary deposits and into even-less-resistant Cretaceous marine shale.

The capture of most drainage from the mountains by the two master streams would have left the Ogallala with no major drains. I am unable to prove that in Miocene time any of these streams was flowing in its present position and depositing the Ogallala. Therefore; I believe that all the streams now crossing the Ogallala started after the beginning of dissection. At the beginning of dissection, the streams on the Ogallala were flowing eastward down the depositional slope; even now the drainage on preserved Ogallala deposits is chiefly eastward. At the end of Ogallala time, the South Platte River probably was north of its position in Pliocene (Nussbaum) time. Eastward from Greeley, the ancestral South Platte River, while downcutting, apparently migrated southward in Pliocene time, the same as the proved movement in most of its reach in Quaternary time. The extent of migration is unknown, but surely was more than $10 \mathrm{mi}(16 \mathrm{~km})$. It moved southward because the principal drainage by tributaries was from the northwest. The southward movement forced the scarp on the south side of the river to retreat southward, kept the reaches of the streams from the south very short, but lengthened the reaches of the streams from the north. The valley of the south Platte was being constantly widened from Pliocene to the present time.

The style of drainage in Pliocene and later time differs considerably from the style in Ogallala time. In Ogallala time most drainage flowed nearly due east from the mountains; in Pliocene and later time the drainage flowed semiparallel to the mountains from three divides, one at the Wyoming border, one at the South Platte-Arkansas divide, and one just north of the New Mexico border, to two master streams, the South 
Platte and Arkansas Rivers. Of the streams joining the South Platte River from the north and south, those to the west developed as major tributaries parallel to and close to the mountains first and then streams to the east gradually were added. New tributaries were added continuously as the scarp on the Ogallala Formation retreated farther and farther east from the mountains and the valleys of the South Platte and Arkansas Rivers were constantly widened. By now, the Ogallala has been removed from more than one half of the area of Colorado east of the mountains.

Enlargement of the drainage area of the South Platte River caused some change in the South Platte-Arkansas divide and in the course of the modern South Platte River. The low area southward from Fort Morgan to River Bend formerly was capped by the Ogallala Formation, but the Ogallala and a considerable thickness of underlying beds were since removed by erosion. All the streams that enter the South Platte River from the south from Brush westward including Beaver, Badger, Bijou, Kiowa, and Box Elder Creeks head in the divide between the Arkansas and South Platte Rivers. Apparently, because of greater activity of these streams than of those south of the divide, the divide has been consistently migrating southward since Ogallala time interrupted only by an occasional stream capture. This divide area is noted for periodic torrential rainfalls that result in catastrophic flash floods. The large amounts of sediment generated by these flash floods in late Pleistocene time dammed the South Platte River, temporarily raised its profile at the mouth of each of the tributaries (especially Bijou Creek), and periodically forced the river against its north valley wall. Mapping by Gardner (1967) suggests that the river had been forced against its south valley wall in Louviers Alluvium time as it was in the rest of its reach in eastern Colorado, but that the southern migration was reversed during deposition of the Broadway Alluvium when the river was forced to move $6 \mathrm{mi}(10 \mathrm{~km})$ northward and cut a new channel in bedrock.

A stream capture involving Big Sandy Creek has been suggested by several authors including Smith (1940, p. 147), Pearl (1971, p. 29) and by Donald L. Coffin of the U.S. Geological Survey (oral commun., 1960). Smith inferred that Big Sandy Creek had captured a northeastward flowing stream near River Bend; Pearl (1971) proposed that Big Sandy Creek had captured the upper part of the ancestral Arikaree River near River Bend. He inferred that the Arikaree River at the close of Ogallala deposition was a major river that originated in the mountains and flowed east down the northeast-trending reach of Big Sandy Creek to join the course of the present Arikaree River.

As stated earlier, I don't believe that an ancestral Arikaree River existed at the end of Ogallala time, but instead, that all of the well-defined streams on the Ogallala originated after the start of dissection in Pliocene time. Indeed, only one of these streams, the South Fork of the Republican River has been incised into the westward-facing scarp of the Ogallala Formation. The other streams arise from tributaries that start east of the scarp. This suggests to me that only the South Fork of the Republican River had any possibility of being an established stream that was beheaded after Ogallala deposition ended. Also, I believe that all drainage across the Ogallala was beheaded by cutting along the mountain front long before creation of present Big Sandy Creek. Both the southeastward and the northeastward reaches of Big Sandy
Creek were created after the Nussbaum Alluvium was deposited 3 m.y. ago. The Nussbaum Alluvium lies about 350 $\mathrm{ft}(107 \mathrm{~m})$ above the floor of Big Sandy Creek and earlier had been transported across the present course of Big Sandy Creek. For this reason, and based on the distribution of the Rocky Flats Alluvium along Big Sandy Creek in the Limon $1^{\circ} \mathrm{x}$ $2^{\circ}$ quadrangle (Sharps, written commun., 1979) I believe that Big Sandy Creek could not have formed any earlier than Rocky Flats time about 1.4 m.y. ago.

In addition, capture of any ancestral Arikaree River also took place long before the Nussbaum Alluvium was deposited, for the Nussbaum lies only about $10 \mathrm{mi}(16 \mathrm{~km})$ west of the scarp of the Ogallala south of Cedar Point and about $350 \mathrm{ft}(107 \mathrm{~m})$ below the eroded top of the Ogallala. Thus, the Ogallala scarp had already retreated about $50 \mathrm{mi}$ $(80 \mathrm{~km})$ from the mountain front in the 2 million years between the end of Ogallala deposition $5 \mathrm{~m} . \mathrm{y}$. ago and deposition of the Nussbaum about $3 \mathrm{~m} . \mathrm{y}$. ago. Since Nussbaum time the retreat has been much slower-about 10 $\mathrm{mi}(16 \mathrm{~km})$ in $3 \mathrm{~m} . \mathrm{y}$. The sharply increased rate of erosion in early Pliocene time is not surprising because this also is the time of greater canyon cutting in the mountains.

Discussions with Coffin, Paul A. Schneider, Jr., and Joseph A. Sharps, all of the U.S. Geological Survey (oral commun., 1979) brought up the fact that Big Sandy Creek is underfit in the reach between River Bend and the Arkansas River. Inasmuch as Big Sandy Creek is underfit, it ultimately was the stream that was captured rather than the stream that did the capturing. Big Sandy Creek probably was originally a much larger stream flowing eastward from near the mountains as shown by both the coarse character of its valley fill and its underfit valley. The valley fill is $70 \mathrm{ft}(21 \mathrm{~m})$ thick and consists of gravelly alluvium that yields large quantities of groundwater to wells (Coffin, 1967).

The drainage history of the River Bend area probably was even more complicated than previously suggested and may have involved three stream captures. A sharp northward bend of East Bijou Creek about $11 \mathrm{mi}(18 \mathrm{~km})$ west of River Bend suggests to me that the upper part of East Bijou Creek formerly was a tributary of a stream farther east, possibly Beaver Creek or Big Sandy Creek. I propose that this upper part of East Bijou Creek flowed eastward across what is now a divide $325 \mathrm{ft}(99 \mathrm{~m})$ higher than Big Sandy Creek and joined ancestral Beaver Creek $2 \mathrm{mi}$ ( $3 \mathrm{~km}$ ) west of River Bend; from there ancestral Beaver Creek flowed northward across what is now a divide $175 \mathrm{ft}(53 \mathrm{~m}$ ) higher than the loop of Big Sandy Creek west of River Bend and joined the modern course of Beaver Creek (fig. 2A). The upper part of ancestral Beaver Creek later was captured near River Bend by the present Big Sandy Creek and the increased large flow which created the broad valley of modern Big Sandy Creek all went southeastward to the Arkansas River (fig. 2B). Finally, the upper part of this Big Sandy Creek, which is now the upper part of East Bijou Creek, was captured, possibly after Slocum time, by modern East Bijou Creek about $11 \mathrm{mi}(18 \mathrm{~km})$ west of River Bend (fig. 2C) and the water was diverted from Big Sandy Creek to the South Platte River. This capture severely diminished the flow of Big Sandy Creek and created the underfit stream we see today. These postulated events probably all took place in Pliocene and early Quaternary time.

The Nussbaum Alluvium was deposited in Pliocene time about 3 m.y. ago and the Rocky Flats Alluvium was deposited starting in Pleistocene time about 1.4 m.y. ago. 

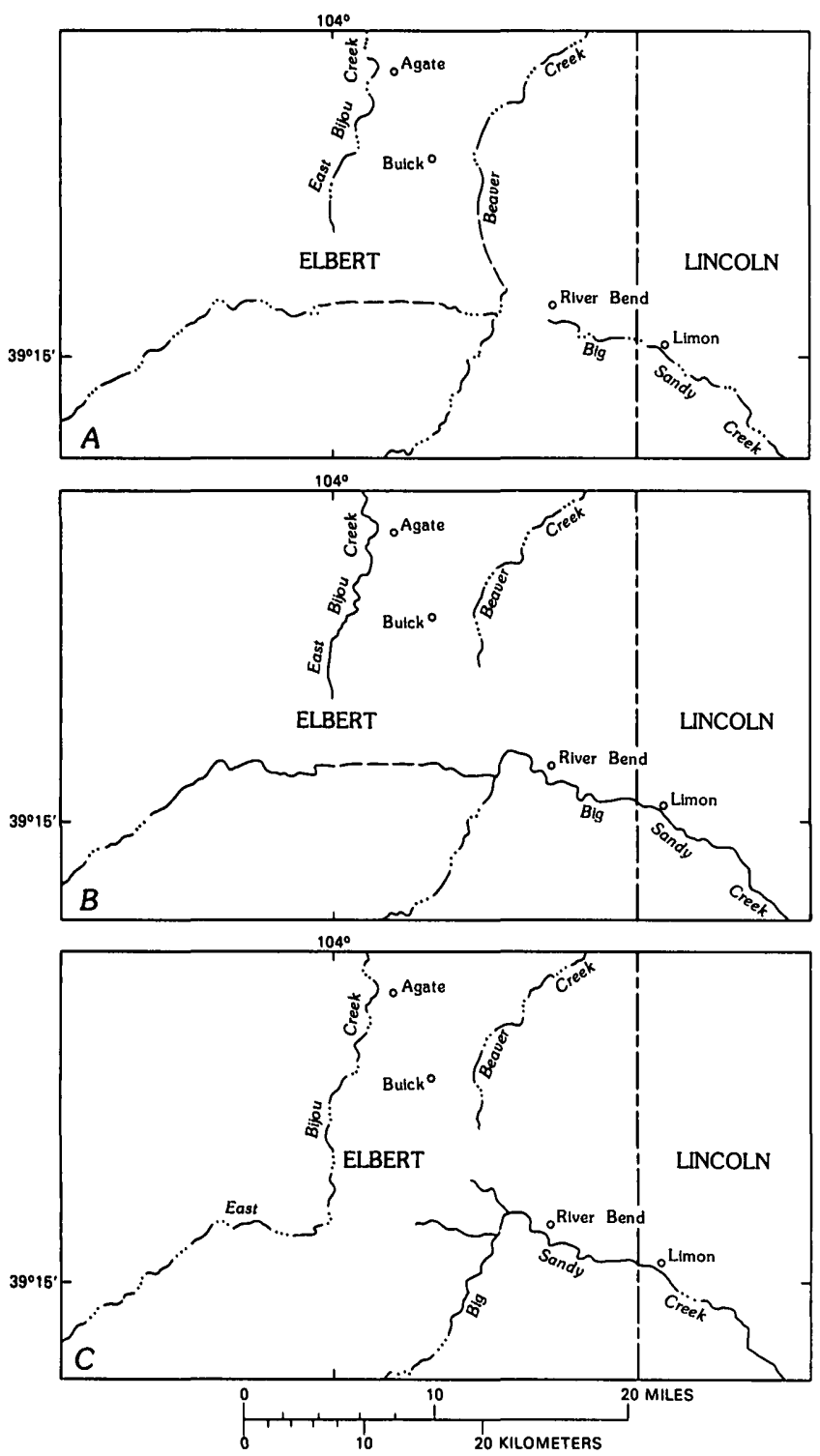

Figure 2.-Diagrams showing postulated stream-course changes involving East Bijou, Beaver, and Big Sandy Creeks. Dashed lines indicate inferred stream courses that no longer exist. $A$, upper part of East Bijou Creek and ancestral Beaver Creek are part of Beaver Creek drainage. B, Big Sandy Creek captures upper part of Beaver Creek. C, East Bijou Creek captures upper part of Big Sandy Creek.

In Quaternary time, southward migration and downcutting of the South Platte River continued. The downward cutting, the result of changed baselevel, has continued to the present time, interrupted less than 10 times when baselevel was stabilized long enough to permit the river to widen its valley floor at progressively lower topographic levels. These levels are the pediments and terraces from which Pliocene and Pleistocene (Blancan) and later Quaternary paleovalleys were inferred. Apparently most of the sediment produced by downward and sideward cutting since Pliocene time was carried out of the Denver basin, the only exceptions being the small amounts of sediment deposited during times of stream stability in the pediment and terrace deposits. The Rocky Flats Alluvium was deposited in early Quaternary time. A cooling climate was causing glaciation in the mountains to the west. The Verdos Alluvium and the Pearlette ash type 0 were deposited. The South Platte River was captured near Barr Lake by a tributary of the Cache la Poudre River and its former channel along Beebe Draw was abandoned. The river moved southward several miles again as the Slocum Alluvium was deposited. The river reached its present position in late Pleistocene (Bull Lake) time or a little bit later. Drainage in the quadrangle was strongly influenced by southeast trending wind-carved valleys and by linear eolian deposits.

In Illinoian time, southeasterly winds started to erode sedimentary rocks in the area, particularly the outwash being carried by the South Platte River. Eolian activity continued through parts of Illinoian, Bull Lake, Pinedale, and Holocene time. The Illinoian deposits (Loveland Loess) and the Bull Lake(?) and Pinedale deposits (Peoria Loess) are composed of wind-blown silt; the Peoria Loess forms definite southeastward trending ridges. Eolian sand was deposited in linear dunes during Pinedale and Holocene time.

\section{REFERENCES CITED}

Blackstone, D. L., Jr., 1975, Late Cretaceous and Cenozoic history of the Laramie Basin region, Southeast Wyoming, in Cenozoic history of the southern Rocky Mountains: Geological Society of America Memoir 144, p. 249-279.

Bryan, Kirk, and Ray, L. L., 1940, Geologic antiquity of the Lindenmeier site in Colorado: Smithsonian Miscellaneous Collections, v. 99, no. 2, pub. 3554, 76 p.

Burbank, W. S., Lovering, T. S., Goddard, E. N., and Eckel, E. B., 1935, Geologic map of Colorado: U.S. Geological Survey, scale 1:500,000.

Clark, John, 1975, Controls of sedimentation and provenance of sediments in the Oligocene of the central Rocky Mountains, in Cenozoic history of the southern Rocky Mountains: Geological Society of America Memoir 144, p. 95-117.

Coffin, D. L., 1967, Geology and ground-water resources of the Big Sandy Creek valley, Lincoln, Cheyenne, and Kiowa Counties, Colorado with a section on chemical quality of the ground water, by C. A. Horr: U.S. Geological Survey Water Supply Paper 1843, 49 p.

Condra, G. E., and Reed, E. C., 1959, The geological section of Nebraska: Nebraska Geological Survey Bulletin 14A, 82 p. [revised from 1943 edition by E. C. Reed].

Corbett, M. K., 1968, Tertiary volcanism of the Specimen-Lulu-Iron Mountain area, North-Central Colorado: in Epis, R. C., ed., Cenozoic volcanism in the Southern Rocky Mountains: Colorado School of Mines Quarterly, v. 63, no. 3, p. 1-37.

Dalquest, Walter W., 1975, Vertebrate fossils from the Blanco local fauna of Texas: Texas Tech Museum Occasional Papers no. 30, 52 p.

Denson, N. M., 1969, Distribution of nonopaque heavy minerals in Miocene and Pliocene rocks of central Wyoming and parts of adjacent states: U.S. Geological Survey Professional Paper 650-C, p. C25-C32.

Denson, N. M., and Chisholm, W. A., 1971, Summary of mineralogic and lithologic characteristics of Tertiary sedimentary rocks in the middle Rocky Mountains and the northern Great Plains: U.S. Geological Survey Professional Paper 750-C, p. C117-C126. 
Epis, R. C., Scott, G. R., Taylor, R. B., and Chapin, C. E., 1976, Cenozoic volcanic, tectonic, and geomorphic features of central Colorado: in Studies in Colorado field geology: Colorado School of Mines Professional Contributions no. 8, p. 323-338.

Galbreath, E. C., 1953, A contribution to the Tertiary geology and paleontology of northeastern Colorado: University of Kansas Paleontological Contributions, Vertebrata, Article 4, 119 p.

Gardner, M. E., 1967, Quaternary and engineering geology of the Orchard, Weldona, and Fort Morgan quadrangles, Morgan County, Colorado: Golden, Colorado School of Mines, D. Sc. dissertation, $283 \mathrm{p}$.

Harksen, J. C., 1969, The Cenozoic history of southwestern South Dakota, in Guidebook to the major Cenozoic deposits of southwestern South Dakota: South Dakota Geological Survey Guidebook 2, p. 11-29.

Hay, O. P., 1917, Descriptions of a new species of Mastodon, Gomphotherium elegans, from the Pleistocene of Kansas: U.S. National Museum, Proceedings 53, p. 219-221.

Izett, G. A., 1975, Late Cenozoic sedimentation and deformation in northern Colorado and adjoining areas, in Cenozoic history of the southern Rocky Mountains: Geological Society of America Memoir 144, p. 179-209. 1977 , Volcanic ash beds in continental deposits of the Southern High Plains: Their bearing on the time of the Blancan-Irvingtonian faunal transition: Geological Society of America Abstracts with Programs, 1977, v. 9, no. 7 , p. 1034 .

Matthew, W. D., 1901, Fossil mammals of the Tertiary of northeastern Colorado: American Museum of Natural History Memoir 1, p. 355-447.

McKenna, M. C., 1965, Stratigraphic nomenclature of the Miocene Hemingford Group, Nebraska: American Museum Novitates, no. 2228, 21 p.

Naeser, C. W., Izett, G. A., and Wilcox, R. E., 1973, Zircon fission-track ages of Pearlette family ash beds in Meade County, Kansas: Geology, v. 1, p. 187-189.

Obradovich, J. D., Izett, G. A., and Naeser, C. W., 1973, Radiometric ages of volcanic ash and pumice beds in the Gering Sandstone (earliest Miocene) of the Arikaree Group, southwestern Nebraska [abs.]: Geological Society of America, Abstracts with Programs (Rocky Mountain Section), v. 5, no. 6, p. 499-500.

Pearl, R. H., 1971, Pliocene drainage of east-central Colorado and northwestern Kansas: Mountain Geologist, v. 8, no. 1, p. 25-30.

Schultz, C. B., Lueninghoener, G. C., and Frankforter, W. D., 1951, A graphic resume of the Pleistocene of Nebraska (with notes on the fossil mammalian remains): Nebraska State Museum Bulletin, v. 3, no. 6, 41 p.

Schultz, C. B., and Stout, T. M., 1945, Pleistocene loess deposits of Nebraska, in Symposium on loess, 1944: American Journal of Science, v. 243, no. 5, p. 231-244. 1955, Classification of Oligocene sediments in Nebraska, a guide for the stratigraphic collecting of fossil mammals: Nebraska State Museum Bulletin vol. 4, no. 2, $52 \mathrm{p}$.

Scott, G. R., 1975, Cenozoic surfaces and deposits in the southern Rocky Mountains, in Cenozoic history of the southern Rocky Mountains: Geological Society of America Memoir 144, p. 227-248.

1978, [1979], Map showing geology, structure, and oil and gas fields in the Sterling $1^{\circ} \times 2^{\circ}$ quadrangle, Colorado, Nebraska, and Kansas: U.S. Geological Survey Miscellaneous Investigations Series Map I-1092, scale 1:250,000.

Scott, G. R., Taylor, R. B., Epis, R. C., and Wobus, R. A., 1978 , Geologic map of the Pueblo $1^{\circ} \times 2^{\circ}$ quadrangle, south-central Colorado: U.S. Geological Survey Miscellaneous Investigations Series Map I-1022, scale $1: 250,000$.

Sharps, J. A., 1969, Lateral migrations of the Arkansas River during the Quaternary-Fowler, Colorado to the Colorado-Kansas State line: U.S. Geological Survey Professional Paper 650-C, p. C66-C70.

1976, Geologic map of the Lamar quadrangle, Colorado and Kansas: U.S. Geological Survey Miscellaneous Investigations Series Map I-944, scale 1:250,000.

Smith, H. T. U., 1940, Geologic Studies in southwestern Kansas: Kansas State Geological Survey Bulletin 34, 212 p., 34 plates.

Smith, R. O., Schneider, P. A., Jr., and Petri, L. R., 1964, Ground-water resources of the South Platte River basin in western Adams and southwestern Weld Counties, Colorado: U.S. Geological Survey Water Supply Paper 1658, $132 \mathrm{p}$.

Soister, P. E., and Tschudy, R. H., 1978, Eocene rocks in the Denver basin: Rocky Mountain Association of Geologists, Field Conference, Guidebook, p. 231-235.

Stanley, K. O., 1976, Sandstone petrofacies in the Cenozoic High Plains sequence, eastern Wyoming and Nebraska: geological Society of America Bulletin, v. 87, no. 2, p. 297-309.

Stanley, K. O., and Wayne, W. J., 1972, Epeirogenic and climatic controls of early Pleistocene fluvial sediment dispersal in Nebraska: Geological Society of America Bulletin, v. 83 , no. 12 , p. $3675-3690$.

Vondra, C. F., Schultz, C. B., and Stout, T. M., 1969, New Members of the Gering Formation (Miocene) in western Nebraska, including A geologic map of Wildcat Ridge and related outliers, by Carl F. Vondra: Nebraska Geological Survey Paper no. 18, $18 \mathrm{p}$.

Wilson, R. W., 1960, Early Miocene rodents and insectivores from northeastern Colorado: University of Kansas Paleontological Contributions, Vertebrata, Article 7, $92 \mathrm{p}$.

Wood, H. E., II, Chaney, R. W., Clark, John, Colbert, E. H., Jepsen, G. L., Reeside, J. B., Jr., and Stock, Chester, 1941, Nomenclature and correlation of the North American continental Tertiary: Geological Society of America Bulletin, v. 52 , no. 1, p. 1-48. 